\title{
ROOTS DISTRIBUTION UNDER DEFICIT IRRIGATION FOR MAIZE PRODUCTION
}

\author{
Khedr, A. F. ${ }^{1}$; EIGamal, R. A. ${ }^{2}$ and Rashad, M. A. ${ }^{3}$
}

\section{ABSTRACT}

Root growth and its distribution is fundamental in explaining crop responses to irrigation systems and determining its appropriate management. An experiment was conducted to study the effect of drip emitters (Em) under full and deficit irrigation on root distribution, yield and water use efficiency (WUE) of maize crop in sandy soil. Four emitter types were used to irrigate the crop by three percentages 100, 80 and $60 \%$ of evapotranspiration $\left(E T_{c}\right)$. The emitters discharge and emission uniformity (EU) were evaluated. Under operating pressure of $100 \mathrm{kPa}$, the emitters Em $1, E m_{2}, E m_{3}$ were classified as excellent EU, while the $E_{4}$ was poor EU. The root distribution increased by increasing emitter $E U$ with low discharge. Also, the distribution root decreased by reducing $E T_{c} \%$ and increasing the distance from emitter. $60 \% E T_{c}$ concentrated the roots near the emitters, while, $80 \% E T_{c}$ has enough distribution to increase the plant ability to withstand winds. The highest yield was achieved with $100 \% E_{c}$ and Em, while WUE of both $60 \%$ and $80 \%$ was approximately the same and greater than WUE of $100 \% E T_{c}$. It could be recommended that to have the highest yield of maize in sandy soil, a low discharge and excellent EU emitters should be used with adding 100\% $E T_{c}$. While, adding $80 \% E T_{c}$ is preferred when the priority to water saving.

Keywords: Root distribution, Emitters, Emission uniformity, Water use efficiency and Evapotranspiration.

\section{INTRODUCTION}

To manage water scarce supplies, deficit irrigation, defined as the application of water below full crop-water requirements 1 (evapotranspiration), is an important tool to achieve the goal of reducing irrigation water use. Although, deficit irrigation is widely practiced over millions of hectares, it has not received the sufficient attention in research (Fereres and Soriano, 2007).

\footnotetext{
${ }_{1,2}$ Assistant Prof. of Agric. Eng., Agric. Eng. Dep., Fac. of Agric., Suez Canal Univ.

${ }^{3}$ Associate Prof. of Agric. Eng., Agric. Eng. Dep., Fac. of Agric., Suez Canal Univ.
} 
Microirrigation systems have lower energy requirement, more effective and less expensive than other irrigation systems. It saves water to the extent of 30 to $70 \%$ without significantly affecting the crop yield (Pandey et al., 2003; 2006). Drip irrigation is also considered as highly efficient system because it allows small but frequent application of water with minimum losses (Locascio, 2005). The distance that water spreads horizontally from a drip line and the volume of soil wetted are play an important role in designing of drip irrigation system (Skaggs et al., 2010). The water movement and its distribution in the soil depends upon many parameters such as the soil type, emitter discharge, quality of water applied, antecedent moisture content, depth of water table and certain climatic factors too. The rate of applying water in drip irrigation system is an important factor, which governs moisture distribution in soil profile. Soil water movement under drip irrigation will also be affected by a high discharge rate which may cause deep percolation losses whereas very low rate may contribute to evaporation losses (El-Meseery, 2011). Emission uniformity is an important parameter to explain the discharge variations along the lateral lines ( $\mathbf{L i}$ et al., 2012). It is essential to understand hydraulic performance of drip irrigation system in relation to soil moisture distribution. Emitter is the critical component of drip irrigation system through which water is delivered precisely to satisfy the crop water requirement. Therefore, the selection of appropriate type of emitters will not only discharges the desired quantity of water but will also render the exact wetting pattern (Ragheb et al., 2011). Considering all other factors of production at their optimum level, crop response is defined as a crop yield decreased constantly by decreasing quantity of water applied into the root zone in deficit irrigation (Amer, 2010); nevertheless, crop yield is decreased constantly by increasing quantity of water applied in surplus irrigation.

In general, soil water uptake pattern is correlated to root distributions, which have been found to depend mostly on the availability of soil water and type of irrigation system. Characterization of root growth and distribution is fundamental in explaining crop responses to irrigation and in determining appropriate management of irrigation systems, particularly with drip systems since it is widely believed that drip irrigation may limit 
the extent of root development (Mansour et al., 2015). Information on root growth patterns is crucial to understand cultivar adaptations to deficit irrigation, particularly for drip-irrigated crops, where root systems are more confined than furrow. Crop cultivars differ in root growth adjustments to soil moisture deficit depending upon their interactions with soil type (Sharma et al., 2018). The rooting depth and root distribution define the soil volume that plants can potentially explore to extract water and nutrients (Fan et al., 2016).

Maize (Zea mays L.) is considered one of the most important cereal crops in the world. Therefore, microirrigation systems with low head could be suggested for maize cultivation. Maize yield production and water use efficiency increased with increasing irrigation frequency and rate under drip irrigation system (El-Hendawy and Schmidhalter, 2010). A high productivity of corn $(4.6 \mathrm{Mg} / \mathrm{fed})$ under drip irrigation in sandy soil was obtained with water use efficiency of $1.92 \mathrm{~kg} \mathrm{~m}^{-3}$, when applied amount of water is full plant requirement (El-Meseery, 2003).

Therefore, the main goal of the present study is to determine the effect of deficit irrigation and emission uniformity (as a function of emitter type) on root distribution and water use efficiency of maize in a sandy soil.

\section{MATERIALS AND METHODS}

To achieve the research goals, four different emitters and three water percentages as 100, 80 and $60 \%$ of evapotranspiration $\left(E T_{c}\right)$ were applied.

\section{Hydraulic Evaluation}

The four emitters $(E m)$ chosen with a same nominal discharge of $4.0 \mathrm{Ch}^{-1}$. An experiment was carried out to calibrate the selected emitters discharge. The emitter flow rate, $q\left(\ell h^{-1}\right)$ was estimated under different operating pressure heads $h_{i}(\mathrm{~m})$, according to the following equation (ASABE, 2008):

$$
q=k h_{i}^{x}
$$

Where, $k$ is the dimensionless constant of proportionality that characterizes each emitter, $x$ is the dimensionless emitter discharge exponent that is characterized by the flow regime.

The emission uniformity of the emitters was tested by using an experimental schematic layout of drip irrigation system, including 12 
similar subunits (three for each emitter). Each subunit consists of three laterals with $30 \mathrm{~m}$ length at distance of $0.75 \mathrm{~m}$, and $0.3 \mathrm{~m}$ interval between emitters. Each subunit was equipped with a valve and pressure gauge. All subunits were connected to a control station equipped with a pressure gauge water meter and pumped fresh Water from Nile river (figure 1).

The emission uniformity ( $E U$ ) plays an important role in root distribution, yield and water use efficiency. The irrigation unit was tested under different operating pressure $(20,40,60,80,100$ and $120 \mathrm{kPa})$ to determine the emission uniformity (EU\%), calculated using the following equation (Li et al., 2012):

$$
E U=\frac{q_{n}}{\bar{q}} \times 100
$$

Where, $q_{n}$ is the average of the lowest quarter emitter flow rates $\left(\ell h^{-1}\right)$ and $\bar{q}$ is the average of all emitters flow rates $\left(\ell h^{-1}\right)$.

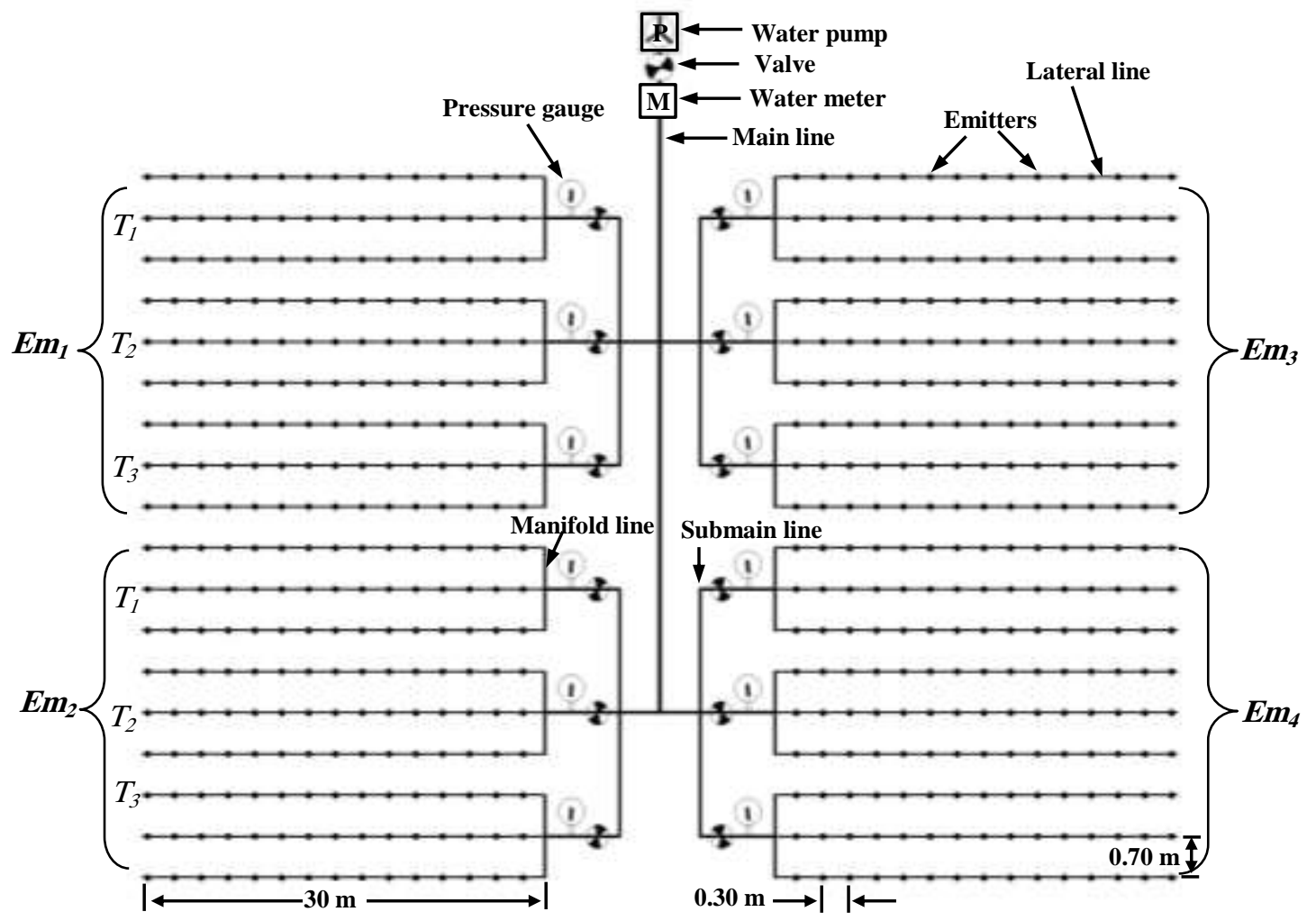

Figure (1): Experimental schematic layout used in the study. 


\section{Field Experiment}

A field experiment was carried out by planting Maize crop (Zea mays L.) during the summer season of 2018 (from $1^{\text {st }}$ May to $18^{\text {th }}$ August) in the Research Farm of Faculty of Agriculture, Ismailia, Egypt. The constructed drip irrigation system (figure 1) was used under operating pressure of $100 \mathrm{kPa}$ to grow one plant at each emitter. This experiment was achieved to examine how root distribution and water use efficiency (WUE) could be affected by a changing emitter type and water deficit. The filed has a homogeneous sandy soil in the tested depth layers as shown in table (1).

Table (1): Physical characteristics of the experimental field soil.

\begin{tabular}{ccccccccc}
\hline $\begin{array}{c}\text { Soil } \\
\text { depth } \\
(\mathrm{cm})\end{array}$ & \multicolumn{2}{c}{ Particle size } & distribution $\%$ & $\begin{array}{c}\text { Texture } \\
\text { Class }\end{array}$ & $\begin{array}{c}D B D \\
\left(\mathrm{~g} / \mathrm{cm}^{3}\right)\end{array}$ & $\begin{array}{c}F C \\
(\%)\end{array}$ & $\begin{array}{c}P W P \\
(\%)\end{array}$ & $\begin{array}{c}A W \\
(\%)\end{array}$ \\
\hline $0-20$ & 95.20 & 2.50 & 2.30 & Sand & 1.63 & 8.7 & 1.7 & 7.0 \\
$20-40$ & 96.67 & 1.53 & 1.80 & Sand & 1.65 & 8.9 & 1.8 & 7.1 \\
$40-60$ & 97.02 & 1.05 & 1.93 & Sand & 1.64 & 8.5 & 1.8 & 6.7 \\
\hline
\end{tabular}

$D B D$ : Dry bulk density, $F C$ : Field capacity (- 0.1 atm), $P W P$ : Permanent wilting point (- $15 \mathrm{~atm})$, and $A W$ : Available water.

Irrigation water requirements (IWR) of maize through the growing season were calculated based on the determination of crop evapotranspiration $\left(E T_{c}, \mathrm{~mm} /\right.$ day) by the Penman-Monteith equation which recommended by FAO (Allen et al., 2011) using CROPWAT software (v. 8.0):

$$
\begin{aligned}
& E T_{c}=E T_{o} \cdot k_{c} \\
& I W R=E T_{c} \cdot A \cdot F
\end{aligned}
$$

Where, $E T_{o}$ is the reference evapotranspiration ( $\mathrm{mm} /$ day), $k_{c}$ is the crop coefficients, IWR is amount of applied irrigation water ( $\ell /$ Irri.), $A$ is the plant area $\left(\mathrm{m}^{2}\right)$ and $F$ is the irrigation frequency.

Three irrigation water percentages from requirements as 100, 80 and 60\% of evapotranspiration $\left(E T_{c}\right)$ were applied. The water application time for each $E T_{c} \%$ was calculated from the following equation:

$$
I_{t}=\frac{I W R}{q}
$$

Where, $I_{t}$ is water application time (h) and $q$ is the emitter discharge $\left(\ell h^{-1}\right)$. 
In order to determine the root density, samples were obtained at the dough growth stage. The samples were collected manually using a soil cylinder has a diameter of $8 \mathrm{~cm}$ and a depth of $10 \mathrm{~cm}$ with a total volume of 500 $\mathrm{cm}^{3}$. Root samples were taken from centers of 10,20 and $30 \mathrm{~cm}$ distances from emitter through a depth of $60 \mathrm{~cm}$ each layer $10 \mathrm{~cm}$ increment. Roots were separated and dried in electrical oven at $70{ }^{\circ} \mathrm{C}$. The computer software SURFER program was used to draw the graphs for the root distribution pattern.

To understand how WUE could be affected by a changing emitter type and water deficit, it will be necessary to determine how these changes will impact plant growth and water use of the plant. To achieve this understanding requires we examine WUE, calculated by the following equation:

$$
F W U E\left(\mathrm{~kg} \mathrm{~m}^{-3}\right)=\frac{\text { Grain yield }\left(\mathrm{kg} \mathrm{fed}^{-1}\right)}{\text { Water applied }\left(\mathrm{m}^{3} \mathrm{fed}^{-1}\right)}
$$

\section{RESULTS AND DISCUSSION}

\section{Drip Irrigation Hydraulic Characteristics}

The water application rate versus operating pressure relationship plays a vital role in the characterization of emitters. It is one of the key factors in selecting an emitter type and system design. table (2) shows the variation between actual and nominal emitter discharge under operating pressure of $100 \mathrm{kPa}$ with emitter discharge constants $(k, x)$ in equation (1). The field emission uniformity $(E U)$ was calculated by equation (2) and the results are shown in table (2) figure (2). Emitters can be classified based on the $E U$ values as excellent uniformity (above 90\%), good (80 to 90\%), fair (70 to $80 \%$ ), poor (60 to $70 \%$ ), and unacceptable (below 60\%) according to ASABE EP 458.0 (1999). From figure (2), it can be seen that under all operating pressures (20 to $120 \mathrm{kPa}$ ), the emitter $E m_{1}$ gives the highest emission uniformity with values higher than $90 \%$ which classified as excellent. The emitters $E m_{2}$ and $E m_{3}$ also gives a high emission uniformity with values ranged from 85 to $93 \%$ which classified from good to excellent based on the operating pressure (table 2). On the other hand, the emitter $E m_{4}$ showed a very low uniformity ranged from 60 to 
$70 \%$ and classified as poor. These results revealed that the $E U$ is mainly dependent on the emitter type.

Table (2): Hydraulic characteristics of tested emitters at operating pressure of $100 \mathrm{kPa}$.

\begin{tabular}{|c|c|c|c|c|c|}
\hline \multirow{2}{*}{ Emitter } & \multirow{2}{*}{$\begin{array}{c}\text { Discharge } \\
\ell h^{-1}\end{array}$} & \multicolumn{2}{|c|}{ Constants } & \multirow{2}{*}{$\begin{array}{c}E U \\
\%\end{array}$} & \multirow{2}{*}{ Classification } \\
\hline & & $k$ & $X$ & & \\
\hline$E m_{1}$ & 3.95 & 0.61 & 0.38 & 94.88 & Excellent \\
\hline$E m_{2}$ & 4.36 & 2.52 & 0.12 & 92.51 & Excellent \\
\hline $\mathrm{Em}_{3}$ & 5.60 & 1.33 & 0.32 & 92.98 & Excellent \\
\hline$E m_{4}$ & 20.56 & 2.04 & 0.50 & 68.67 & Poor \\
\hline
\end{tabular}

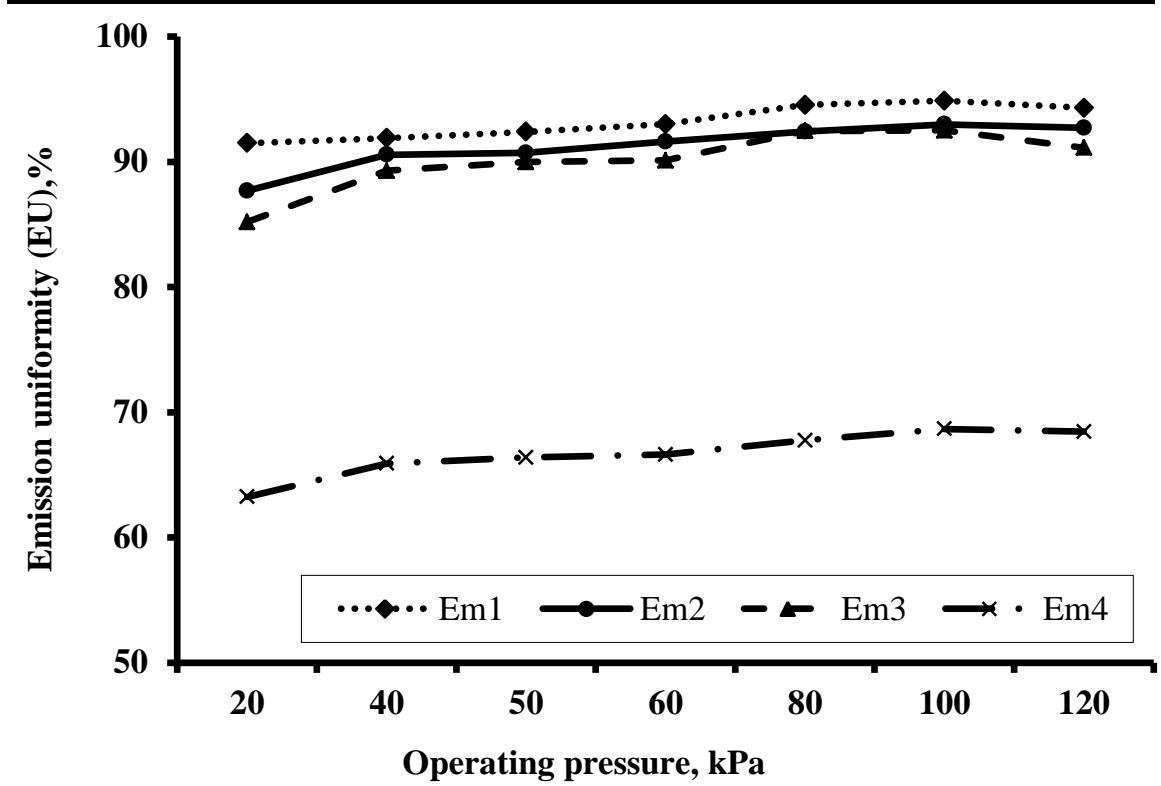

Figure (2): The emission uniformity of tested emitters under different operating pressure.

All emitters reached the highest uniformity by increasing operating pressure up to $100 \mathrm{kPa}$. While, uniformity decreased with further increasing in operating pressure to $120 \mathrm{kPa}$ as shown in (Figure 2). Therefore, the field experiment was carried out under the operating pressure of $100 \mathrm{kPa}$. It is noticeable that, the emission uniformity of drip emitters increased by reducing their flow rate. 


\section{Roots Distribution and Density}

Effect of applied water as a percentage from evapotranspiration $\left(\mathrm{ET}_{\mathrm{c}} \%\right)$ on the root distribution was summarized in table (3) and presented graphically in figure (3). At all tested $E T_{c}$, the root density percentage $\left(R_{d}\right.$ $\%)$ increased proportionally by decreasing the soil depth and the horizontal distance $\left(H_{d}\right)$ from emitter. For instance, the location adjacent the emitter at 0 to $10 \mathrm{~cm}$ horizontally in depth from 0 to $60 \mathrm{~cm}$ has the highest root density ranged from 56.95 to $78.33 \%$.

Table (3): Root distribution of maize in horizontal distance $\left(H_{d}, \mathrm{~cm}\right)$ from emitters $(E m)$ under different crop evapotranspiration percentage $\left(E T_{c} \%\right)$.

\begin{tabular}{|c|c|c|c|c|c|c|c|c|c|}
\hline \multicolumn{2}{|c|}{ Emitter } & \multicolumn{2}{|c|}{$E m_{1}$} & \multicolumn{2}{|c|}{$E m_{2}$} & \multicolumn{2}{|c|}{$\mathrm{Em}_{3}$} & \multicolumn{2}{|c|}{$\mathrm{Em}_{4}$} \\
\hline$\therefore \rightarrow$ & 3 & $\begin{array}{c}\text { Int. } \\
\text { g/500 } \\
\mathrm{cm}^{3} \\
\end{array}$ & $\begin{array}{c}\text { Den. } \\
\%\end{array}$ & $\begin{array}{l}\text { Int. } \\
\text { g/500 } \\
\mathbf{c m}^{3}\end{array}$ & $\begin{array}{c}\text { Den. } \\
\%\end{array}$ & $\begin{array}{l}\text { Int. } \\
\text { g/500 } \\
\mathbf{c m}^{3} \\
\end{array}$ & $\begin{array}{c}\text { Den. } \\
\%\end{array}$ & $\begin{array}{c}\text { Int. } \\
\mathrm{g} / 500 \\
\mathrm{~cm}^{3} \\
\end{array}$ & $\begin{array}{c}\text { Den. } \\
\%\end{array}$ \\
\hline \multirow{4}{*}{100} & $0-10$ & 2.33 & 66.01 & 2.16 & 63.34 & 1.59 & 58.03 & 1.68 & 56.95 \\
\hline & $10-20$ & 0.90 & 25.50 & 0.90 & 26.39 & 0.69 & 25.18 & 0.69 & 23.39 \\
\hline & $20-30$ & 0.30 & 8.50 & 0.35 & 10.26 & 0.46 & 16.79 & 0.58 & 19.66 \\
\hline & Total & 3.53 & 100 & 3.41 & 100 & 2.74 & 100 & 2.95 & 100 \\
\hline \multirow{4}{*}{80} & $0-10$ & 1.81 & 69.35 & 1.65 & 63.46 & 1.27 & 60.48 & 1.22 & 59.22 \\
\hline & $10-20$ & 0.63 & 24.14 & 0.65 & 25.00 & 0.51 & 24.29 & 0.45 & 21.84 \\
\hline & $20-30$ & 0.17 & 6.51 & 0.30 & 11.54 & 0.32 & 15.24 & 0.39 & 18.93 \\
\hline & Total & 2.61 & 100 & 2.60 & 100 & 2.1 & 100 & 2.06 & 100 \\
\hline \multirow{4}{*}{60} & $0-10$ & 1.19 & 77.78 & 0.94 & 78.33 & 0.71 & 75.53 & 0.56 & 73.68 \\
\hline & $10-20$ & 0.34 & 22.22 & 0.26 & 21.67 & 0.23 & 24.47 & 0.2 & 26.32 \\
\hline & $20-30$ & 0.00 & 0.00 & 0.00 & 0.00 & 0 & 0.00 & 0 & 0.00 \\
\hline & Total & 1.53 & 100 & 1.20 & 100 & 0.94 & 100 & 0.76 & 100 \\
\hline
\end{tabular}

*The values of root intensity and density at each location are the total roots intensity in the tested depth layers from 0 to $60 \mathrm{~cm}$

The highest root distribution was recorded by irrigated the full water requirements $\left(100 \% E T_{c}\right)$, that supporting plants against the wind in the soil, beside obtaining a high yield. The irrigation by $80 \% E T_{c}$ saving $20 \%$ of water requirements and gives a roots distribution in the soil layer from 0 to $40 \mathrm{~cm}$, which is considered enough to support the plant against the wind, proved required water for growing and gives acceptable yield. 


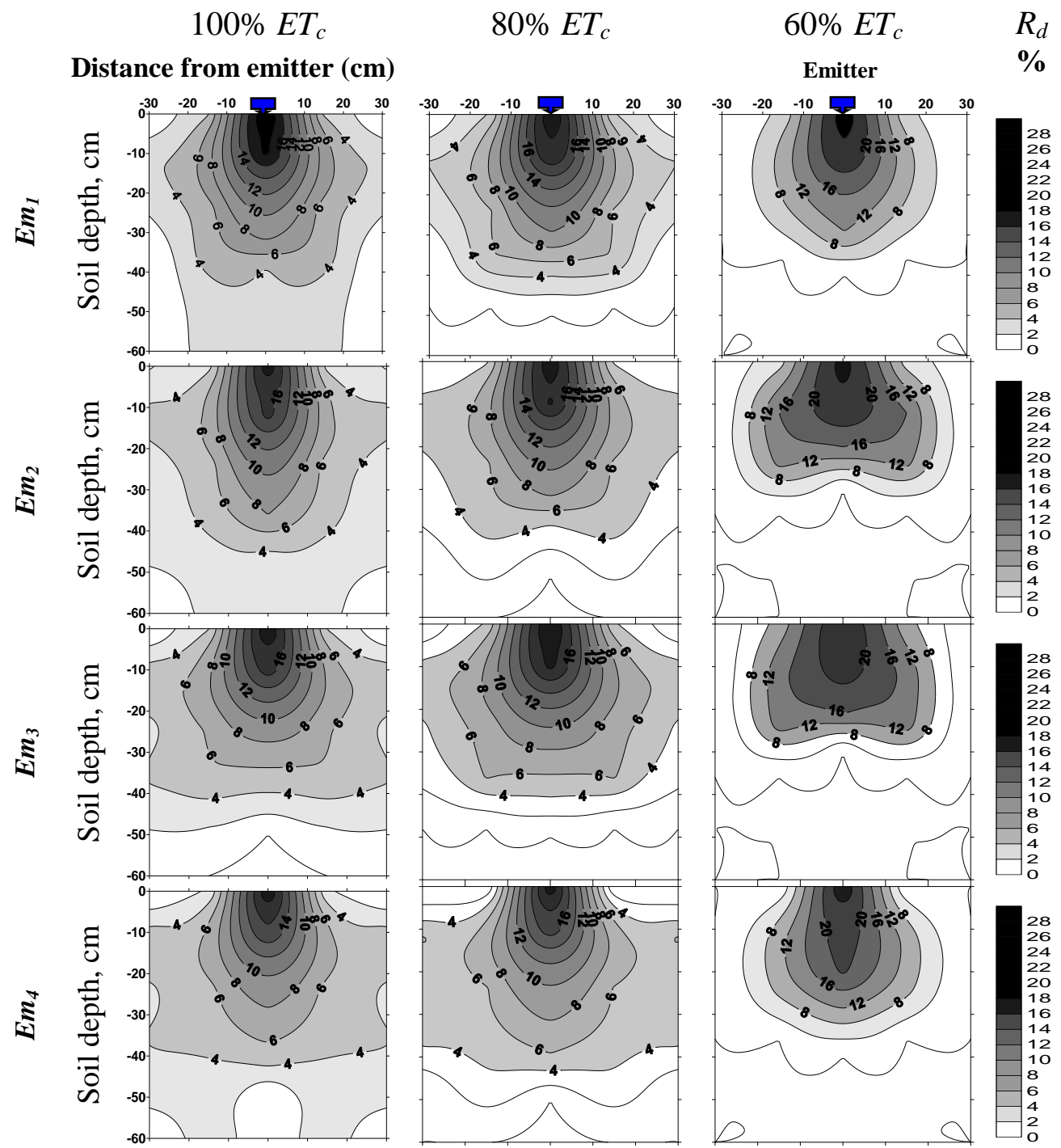

Figure (3): Root distribution pattern of maize plant for different emitters under different water treatments.

Although, $60 \% E T_{c}$ saving $40 \%$ of irrigation water, it gives a poor root distribution compared to other irrigation rates (in the soil layer from 0 to $30 \mathrm{~cm}$ ), which decrease the plant ability to withstand winds. It can be also seen from figure (3) that emitter $E m_{1}$ gives the highest uniform distribution patterns for roots under different water treatments. These results due to the high emission uniformity and the low discharge of $E m_{1}$ among all tested emitters. 


\section{Yield of Maize}

In general, it could be noticed that the maize yield decreases by increasing deficit irrigation for all tested emitters as shown in figure (4). For example, the maximum yield of maize is obtained by adding full water requirements to the plant $\left(100 \% E T_{c}\right)$. The maize production was acceptable by adding $80 \% E T_{c}$, because the soil water did not expose to a high stress. As, the maize plant is classified as drought sensitive crop, the application of $60 \% E T_{c}$ resulted in a lowest yield.

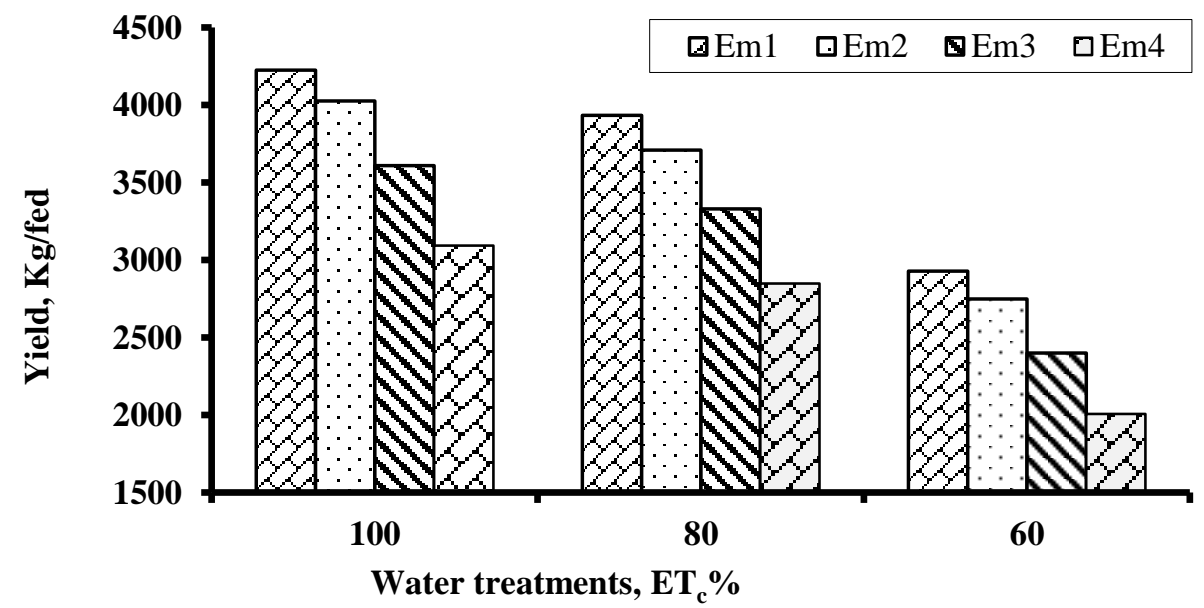

Figure (4): Effect of applied water as $E T_{c} \%$ by drip emitters (Em) on maize yield.

It can be also indicated from figure (4) that under all applied water quantities $E T_{c} \%$, the emitter $E m_{1}$ gives the highest yield. This due to its highest emission and root distribution uniformity. Moreover, the yield of $E m_{1}$ decreased only 7\% (from 4226 to $3935 \mathrm{~kg} / \mathrm{fed}$ ) by reducing applied water by $20 \%\left(80 \% E T_{c}\right)$ for $E m_{1}$. While, reducing $40 \%$ of water $(60 \%$ $E T_{c}$ ) decreasing the yield to $2930 \mathrm{~kg} / \mathrm{fed}$ by $31 \%$ as shown in Figure (4). Accordingly, $60 \% E T_{c}$ could not be recommended for maze production in sandy soil.

\section{Water Use Efficiency}

Water use efficiency (WUE) is a ratio between grain yield and total amount of applied water. The efficient use of applied water as $E T_{c} \%$ was graphically illustrated in figure (5). It can be seen that, WUE was increased by decreasing added $E T_{c} \%$ from 100 to both 80 and $60 \%$ for all 
emitters. Applying of $E T_{c} 80$ and $60 \%$ gives a very close values of $W U E$ for each tested emitter except $E m_{4}$ showed a clear decrease in its WUE. This due to the poor $E U$ classification of $E m_{4}$. It is clear from the obtained results (figure 5) that the highest value of $W U E$ was achieved for emitter $E m_{1}$ at $80 \% E T_{c}$, which could be recommended for drip irrigated maize in sandy soil.

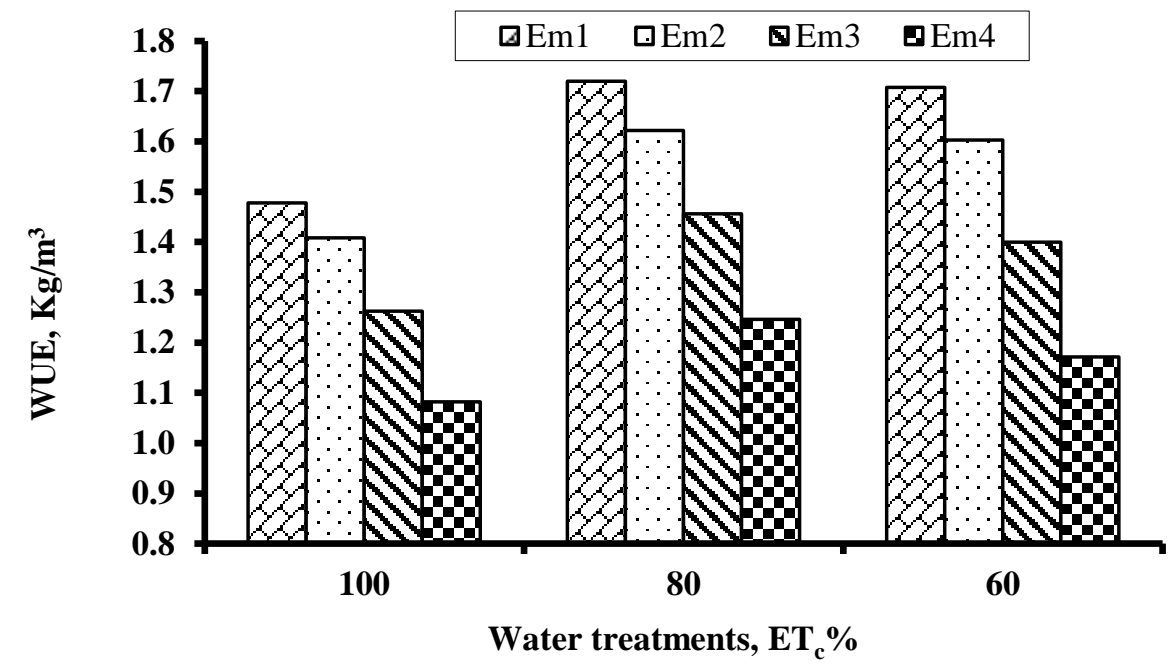

Figure (5): Effect of applied water as $E T_{c} \%$ on water use efficiency for different emitters.

\section{CONCLUSION}

The main objective of this research work was to investigate the effect of using different emitter types $(\mathrm{Em})$ under adding water requirement as 100 , 80 and $60 \%$ of $E T_{c}$ on root distribution, maize yield and water use efficiency (WUE) in sandy soil. The results could be summarized as:

1- The actual emitter discharge under operating pressure of $100 \mathrm{kPa}$, was arranged as $E m_{1}<E m_{2}<E m_{3}<E m_{4}$. The $E U$ of $E m_{1}, E m_{2}$ and $E m_{3}$ were excellent, but $E m_{4}$ poor flowed this order $E m_{1}>E m_{2}>E m_{3}>E m_{4}$.

2- The root distribution and yield were increased by increasing $E T_{c} \%$ and $E U$.

3- $60 \% E T_{c}$ concentrated the roots at less than $25 \mathrm{~cm}$ horizontally in the upper soil layer, while, $80 \% E T_{c}$ distributed the roots at more than $30 \mathrm{~cm}$ horizontally in depth 0 to $40 \mathrm{~cm}$, which increasing a plant ability to withstand winds. 
4- WUE was increased by increasing deficit irrigation. WUE was approximately the same by reducing $E T_{c}$ from 80 to $60 \%$ for $E m_{l}$, $E m_{2}$ and $E m_{3}$, but it decreased for $E m_{4}$.

5- It could be recommended that to have the highest yield of maize in sandy soil, a low discharge and excellent $E U$ emitters should be used with adding $100 \% E T_{c}$. While, adding $80 \% E T_{c}$ is preferred when the priority to water saving.

\section{REFERENCES}

Allen, R. G.; L. S. Pereira; R. Dirk and M. Smith (2011). Crop Evapotranspiration Guidelines for computing crop water requirements. FAO Irrigation and Drainage Paper No. 56, 1998. Food and Agriculture Organization. Rome, Italy, pp. 83.

Amer, K. H. (2010). Corn crop response under managing different irrigation and salinity levels. Agric. Water Manage., (97), 1553 -1663.

ASABE EP 405.1 (2008). Design and installation of microirrigation Systems. ASAE, 1 - 5.

ASABE EP 458.0 (1999). Field evaluation of microirrigation systems. St. Joseph, Michigan, ASAE, 792 - 797.

El-Hendawy, S. E. and U. Schmidhalter (2010). Optimal coupling combinations between irrigation frequency and rate for drip-irrigated maize grown on sandy soil. Agric. Water Manag., Elsevier, 97(3): 439 - 448.

El-Meseery, A. A. (2003). Effect of different drip irrigation systems on maize yield in sandy soil. The $11^{\text {th }}$ Annual conference of Misr J. Agric. Eng., 15-16 Oct., 576 - 594.

El-Meseery, A. A. (2011). Water movement in soil under micro trickle irrigation system. Misr J. Agric. Eng., 28(3): 612 - 629.

Fan, J.; B. McConkey.; H. Wang and H. Janzen (2016). Root distribution by depth for temperate agricultural crops. Field Crops Res 189: 68 - 74. 
Fereres, E. and M. A. Soriano (2007). Deficit irrigation for reducing agricultural water use. Journal of Experimental Botany, 58 (2): 147 159.

Li, J.; W. Zhao; J. Yin; H. Zhang; Y. Li and J. Wen (2012). The effects of drip irrigation system uniformity on soil water and nitrogen distributions. Trans. of the ASABE., 55(2): 415 - 427.

Locascio, J. S. (2005). Management of irrigation for vegetables: past, present, future, Hort technology, 15(3): 482 - 485.

Mansour H. A.; K. h. Pibars and V. F. Bralts (2015). Performance of Automatic Control Drip Irrigation System and Farm Topography for Soil Moisture Distribution, Mung Bean Grain Yield and Water Productivity. Global Advanced Research J. 4(8): 415 - 424.

Pandey, A.; P. P. Dabral; D. Kumar and M. Billib (2006). Moisture distribution of drip emitters in sandy soil-A laboratory study. J. A. Irrig. Sci., 41 (1): 21 - 33.

Pandey, A.; G. S. Rajput and S. K. Shrivastava (2003). Effect of drip Irrigation on soil moisture distribution in clay soils of Madhya Pradesh-A case study. Indian J. Soil Cons., 31(3): 248 - 252.

Ragheb, H. M.; M. A. Gameh; S. M. Ismail and N. A Abou Al-Rejal (2011). Water distribution patterns of drip irrigation in sandy calcareous soil as affected by discharge rate and amount of irrigation water. JKAU: Met., Env. \& Arid Land Agric. Sci., 22(3): 141 - 161.

Sharma S. P.; D. I. Leskovar; A. Volder; K. M. Crosby and A. M. Ibrahim (2018). Root distribution patterns of reticulatus and inodorus melon (Cucumis melo L.) under subsurface deficit irrigation. Irrig. Sci., 36: $301-317$.

Skaggs, T. H.; T. J. Thomas and Y. Rothfuss (2010). Drip irrigation water distribution patterns: Effects of emitter rate, Pulsing, and Antecedent Water. Soil Sci. Soci. America J., 74(6): 1886 - 1896. 


\section{الملخص العربي \\ إنتثار الجذور تحت نقص مياه الرى لإنتاج محصول الذرة الزبي \\ أحمد فتحى محمد خضر' ، رمضان عبد الحميد الجمل ' و محمـ أبوزيد رشـادّا}

نمو الجذور ومدى إنتشارها أحد الوسائل الأساسية لتوضيح مدى إستجابة المحصول المزروع

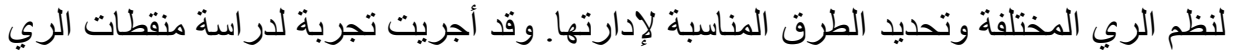

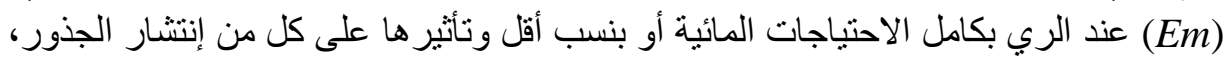
المحصول، وكفاءة استهلاك المياه (WUE) لمحصول الذرة بالتربة الرملية. و عليه تم إستخدام

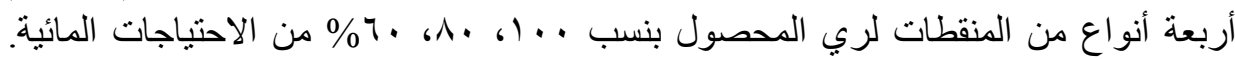
وكذللك أجريت معايرة للمنقطات وتم تقييم انتظامية تصرف من (EU) خطوط المنقطات.

أظهرت النتائج ان تصرف المنقطات الفعلية تحت ضغط . ․ كيلوباسكال اختلف من منقط لأخر ويمكن ترتيبها كالتالي EU لخطوط المنقطات الجذور ز اد بزيادة الانتظامية ومع التصرفات الأقل. كذلك قل الانتشار بزيادة الابتعاد عن المنقط وبتقليل نسبة كمية المياه المضافة من الاحتياجات المائية (ET \% • 7٪ من c

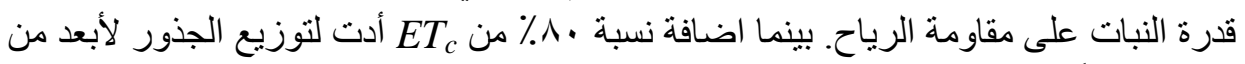

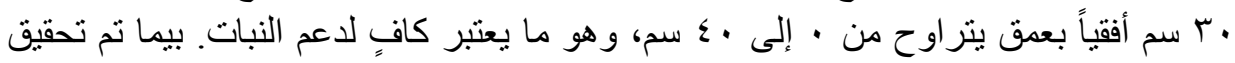

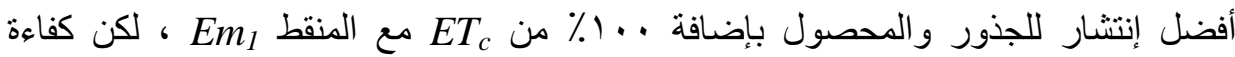

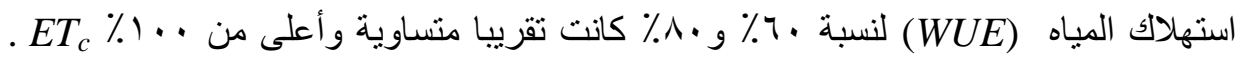

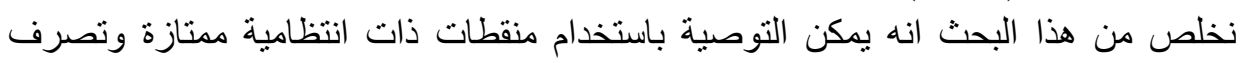

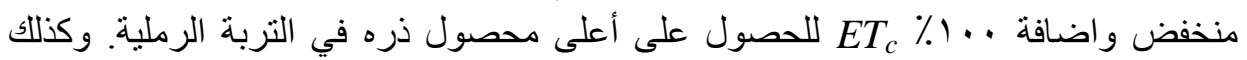

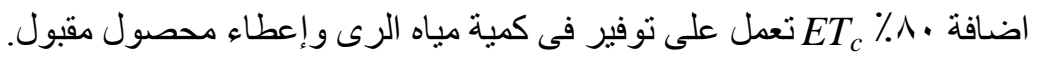

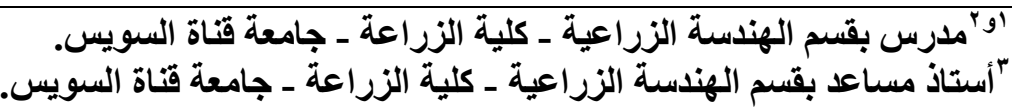

